\title{
The need for discoursing social theology in Muslim Southeast Asia
}

\author{
Azhar Ibrahim \\ Department of Malay Studies National University of Singapore \\ E-mail:mlsai@nus.edu.sg
}

\begin{abstract}
This paper highlights and evaluates the significance of an emerging social theological discourse in contemporary Muslim Southeast Asia. It emerged partly as a response to the traditional Islamic theology inasmuch as the revivalist dakwah activism that became prominent since the 1970s. This emerging discourse is part of the continuity and extension of the reformist voices which have evolved since the late $19^{\text {th }}$ century. As a theology, it puts discourse about God as its premium but extend its focus on the social dimension of faith in God, of the social message of the religion, and the social responsibility of the man and community of faith in God, and to their fellow human beings. Today there are several books and articles written which can be classified as belonging to this genre of social theology. In Indonesia this discursive theology can be found in rational, humanistic, transformative cultural, and the oppressed theologies. It opens a wider realm of participation and engagement, where theology is no longer the exclusive affairs of experts, but inclusive of the lay intellectuals who are not necessarily from a strictly religious background. It also enables the Muslim public to comprehend critically and to cope creatively with rapid social change, and its attendant problems. Theology is, after all, a human enterprise, albeit it's strong religious commitment. To harness the potentiality of the social theology, calls for its recognition. Herein lies the
\end{abstract}


need to start studying and engaging them discerningly, or to advance its critical dimensions for the benefits of the larger Muslim public.

Paper ini menyoroti dan mengevaluasi pentingnya wacana teologi sosial yang muncul dalam periode kontemporer Muslim Asia Tenggara. Teologi sosial muncul sebagian sebagai tanggapan terhadap teologi Islam tradisional karena aktivisme dakwah revivalis yang semakin menonjol sejak tahun 1970-an. Wacana yang muncul di sini merupakan bagian dari kontinuitas dan perluasan suara reformis yang telah berkembang sejak akhir abad ke-19. Sebagai teologi, teologi social menempatkan wacana utama tentang Tuhan tetapi memperluas fokusnya pada dimensi sosial iman kepada Allah, pesan sosial agama, dan tanggung jawab sosial dari komunitas iman kepada Allah, dan terhadap sesama manusia. Saat ini ada beberapa buku dan artikel yang ditulis yang dapat diklasifikasikan sebagai milik genre teologi sosial. Di Indonesia teologi diskursif ini dapat ditemukan dalam teologi-teologi rasional, humanistik, budaya transformatif, dan teologi kaum tertindas. Ini membuka sebuah dunia yang lebih luas bagi partisipasi dan keterlibatan, di mana teologi tidak lagi urusan eksklusif para ahli, tetapi termasuk para intelektual awam yang tidak harus berasal dari latar belakang agama secara ketat. Hal ini juga memungkinkan masyarakat Muslim untuk memahami secara kritis dan kreatif dalam mengatasi perubahan sosial yang cepat dan problem yang muncul. Di luar itu semua, teologi sosial adalah urusan manusia, dengan komitmen keagamaan yang kuat. Untuk memanfaatkan potensi dari teologi sosial, diperlukan panggilan untuk pengakuan. Di sinilah letak kebutuhan untuk mulai mengkaji dan melibatkan teologi sosial, atau mengedepankan dimensi kritis dari teologi sosial agar bermanfaat lebih besar masyarakat Muslim.

Keywords: Social theology; Theological traditions; Public sphere; Reforms

\section{Introduction}

This paper aims to highlight and evaluate the significance of an emerging theological discourse in contemporary Muslim Southeast Asia. This emerging discourse can be identified as social theology. The latter is a composite theological discourses with a public and social character in two 
main dimensions, namely in its thematic and spatial dimensions. As a discourse it can be seen as a part of an emerging reformistic and progressive Islam discourse that is gaining considerable momentum in Indonesia; while in Malaysia, and to some in extent in Singapore, it is gradually gaining ground. This social theology emerged partly as a response to the traditional or orthodox Islamic theology that have dominated the religious life of the people for centuries, inasmuch as it is also an alternative way at understanding theological ideas which are presented to the Muslim public, especially in the midst of the revivalist dakwah activism that became prominent since the 1970s. In a way, one can also say that the emerging discourse is part of the continuity and extension of the reformist and progressive voices of Islam in the religion which have evolved since the late $19^{\text {th }}$ Century.

While historically there was a kind of uniformity in the theological teaching and dissemination in the region, the contemporary period saw a diversity of theological expressions and emphases, and this can be attributed to both endogenous and exogenous dynamics. In recognizing this emerging theological discourse, and evaluating its fundamental ideas, we are basically studying human ideational and valuational endeavors, with its strengths and frailties, commitments and contradictions, and surely its animosity and ambivalences, with a frame of commitment which the believers claim as their faith. Liberative, progressive, conservative, fundamentalist and extremist theologies have emerged throughout history, and often have been used to justify certain ideological interest, or exhibit autopinianistic strand. There can be theological discourse that is dogmatic and exclusive, inasmuch as those that are liberative and pluralistic. The emergence of the latter warrants attention inasmuch as support, in the midst of religious exclusivism that asserts all discourses of Islam as their sole prerogative. Via social theology, articulated in the public do- 
main, new religious idioms and concepts can be socialized and harnessed of its meaning and dissemination.

Generally the study on theologies that have emerged and dominated Muslim Southeast Asia, past and present, has been a neglected field, and mostly confined to historical and textual approaches. ${ }^{1}$ The various studies on Islam in Southeast Asia are generally centered on the issues of religion and politics, the legalistic tradition, ethnicities, institutions, gender, economics, geo-political security and the like. Even if there are studies on the theological traditions in Muslim Southeast Asia, it is generally philological and historical in nature, to the point that we know very little about what is going on today in the local Muslim theological discourse. One can find rather easily on works discussing on legalistic/shariah Islam or the Islamic jurisprudence and shariah laws, in comparison to studies on Muslim theologies, especially as evolved and developed in the Southeast Asian context. We hope that this preliminary study addresses the lacunae in our attempt to understand the role and function of the theology in the Southeast Asian Muslims' thought and practices.

\section{Defining social theology}

Theology as we know is essentially a discourse about God. Social theology similarly puts discourse about God as its premium but extend its focus on the social dimension of faith in God, of the social message of the religion, and the social responsibility of the man and community of faith in God, and to their fellow human beings. A theology that emphasize on the social dimension of the religion and the people's life is not to be seen

\footnotetext{
${ }^{1}$ Refer, Peter Riddell, Transferring a Tradition: Abd al-Ra'uf al-Singkili's Rendering into Malay of the Jalalayn Commentary, Berkeley, CA : University of California, Centers for South and Southeast Asia Studies, 1990; Peter Riddell, "Controversy in Qur'anic Exegesis and Its Relevance to the Malays-Indonesian World," in Anthony Reid (ed.) The making of an Islamic political discourse in Southeast Asia, Clayton, Vic. : Centre of Southeast Asian Studies, Monash University, 1993.
} 
as an alternative to the dogmatic theology that is generally subscribed today. It can be seen as an extension and even elaboration on the latter.

In analyzing social theology, we are interested to look at the social visions of Muslim theologians, scholars and writers. What includes in this realm of "social" ranges on matters concerning politics, culture, economic and education. As mentioned earlier, the thematic and spatial dimensions in social theology are amongst its distinctive features. The new thematic social concerns in the theological repertoire bears an expansion of the field of theology itself as well as the commitment to deliberate the social dimension of the religion, inasmuch as to address the problems and concerns of the society at large. The spatial dimension refers to the locus of the theology. Social theology occupies the public sphere and this is one important feature that distinguishes it from the traditional theology. While social theology intent on engaging the Muslim public, even critical and challenging the status quo, traditional theology, even if it makes a presence in the public sphere, is normally characterized by assertions and normative prescriptions, often made in an authoritarian parlance.

But social theology is not simply a sociological document or analysis on the religious thought and orientation. It is also reflectively theological, inasmuch as it can be a dissenting voice of the present dehumanized conditions. In other words, social theology should function to affirm faith inasmuch it questions some of the fundamental conceptions and preconceived ideas that are found in the dominant theology or the accumulated religious traditions. Social theology in the public sphere can prevent the diminutive presence of religious reasoning in the context of secularization or the ambivalence about religion. A social theology that is critical, pluralistic and transformative in its outlook is also a means to redirect Muslim public inclinations away from the revivalist and fundamentalist theologies that are totalitarian and exclusive in its rhetoric. 
In a way this emerging social theology can be seen as a 'new' form of theologizing attempts in Muslim Southeast Asia. It mirrors the reaction and reflection of the socio-political, cultural and economic realities confronting the people at the present. By 'new' we do not mean an entirely different doctrinal conviction as opposed to the orthodox belief. It refers primarily to a new approach of doing theology, in the articulation of idioms, themes, styles and, with a larger targeted audience directed at. The new works of theologies no longer deal with traditional theology which is heavily medieval/scholastic in its themes, concerns and expressions.

\section{Types of theological orientations in Muslim Southeast Asia}

In Muslim Southeast Asia, theology as generally understood and taught in two main classifications which are interrelated. First is the six article of faith known as arkanulIman ( rukun iman) and the other is the five pillars of the religion known as arkanul Islam (rukun Islam). The former constitutes: a) the belief in the existence of one God; b) the belief in the angels; c) the belief in the Quran and other revealed books; d) the belief in the messengers of God; e) the belief the Day of Judgment and f) the predestination (qada and qadar). The five pillars of Islam entails: a) syahadat or creedal affirmation of tauhid; b) performing the five times daily prayers; $c$ ) observing fasting in the month of Ramadan; d) paying zakat and fitrah; and e) performing the hajj pilgrimage to Mecca for those who have the means.

A general survey of the theological works that have been used in this region is useful to give us some idea of the theological tradition that have been adopted and readapted in this part of the world. In the process of Islamisation, theological treatises and summaries were written, adapted or translated from the Arabic sources. ${ }^{2}$ In the dominant doctrinal dis-

${ }^{2}$ For instance, refer to: G. W. J. Drewes (ed.), Directions for Travellers on the Mystic Path: Zakariyya al-Ansari's Kitab Fath al-Rahman and Its Indonesian Adaptations: with an Appendix on 
course there are clear demarcation between the sciences of Ușul al-Din, the sciences of Ușul al-Figh and tasawuf. This division has been accepted as a standard format of how Islam should be taught and transmitted in religious centers of learning.

Before we move into the discussion on the emerging social theology in Muslim Southeast Asia, we need to know the types of theological orientations that are found today in the region. These are only ideal type typologies, and here we indicate more of an orientation than the content of the theology in substantive terms. The general categories below, however, will only make sense if we look at them as a kind of nuances of themes and emphases, rather than its content per se, inasmuch as there could be an overlapping amongst them. We have identified seven theological orientations that could be found in Malay-Indonesian society. These are:

\section{The traditional creedal theology (aqaid/akidah)}

This notion of theology is still widely taught and disseminated. It is not uncommon today that theology is invariably associated with the five pillars of Islam. The kind of dominant theological discoursing is mainly expository type, with emphasis on tauhid and akidah, be it from the textual and historical standpoints. The teaching of akidah is often made side by side by the emphasized on observing the rules of figh. The content of such akidah is often minimal and basic, meant for the general population. In the general religious instruction to the Muslim public this creedal theology is predominant cast almost in standard format, with a total obedience as a perquisite in learning and accepting the creed.

Palembang Manuscripts and Authors, The Hague: Nijhoff, 1977; Syed Muhammad Naquib al-Attas, (ed.), The Oldest Known Malay Manuscript : a 16th Century Malay Translation of the 'Aqa'id of al-Nasafi, Kuala Lumpur:University of Malaya, 1988. 


\section{The classical orthodox kalam/theology}

In the traditional centers of Islamic learning like pondok/pesantren/ madrasah, the teaching of kalam was framed within the Sunni worldview, with an exposition on the doctrines of Islam by Imam Abul Hasan alAsy'ari and Imam Abu Mansur al-Maturidi. This kalam theology is still being taught in various pondok and pesantren, and local ulamas of the past had written several introductory and summaries for the use of teaching the kalam doctrines on the attributes and acts of God, predestination or the freedom of human will and topics like whether Quran is created or otherwise. This kalam is also known as Ilmu Sifat Dua Puluh dan Ilmu Mengenal Allah. This theological discourse has its long history and very well established in the traditional centers of learning throughout the region, but mostly confined to those who have access to the higher learning of the Islamic sciences.

\section{The Sufistic theology of wah datal-wujūd}

The sufistic theology of wahdat al-wuju $\bar{d}$ is more specific in its emphasis of the sufi mystical path, which it distinguish itself from the philosophical rationality of the falsafah or the legastic figh, which it sees as a hindrance in knowing the True Reality ( Hakikat). This esoteric theosophical sufism, commonly known as wahdat al-wuju d was first introduced in this region by the Achehnese mystic HamzahFansuri in the $16^{\text {th }}$ Century, and his teaching spread throughout the region along with the process of Islamisation. Sufistic theology is characterized by a strong emphasis of attaining the mystical union with God via life of sufi contemplation and worldly renouncement. This theology is mostly confined amongst the sufi brotherhood. Throughout the region this notion of sufism although shunned by the conservative religious establishment, nevertheless commands great reverence amongst the people as a mystical path to attain 
the Truth. In history, this theology had been the subjected to opposition from the conservative religious establishment, and for quite some time it remained underground. ${ }^{3}$

\section{The messianic theology of certain religious communes and congregations}

Amongst some religious communes or congregations, they subscribed to what can be seen as messianic theology, that is characterized by eschatological and apocalyptic emphasis in the coming of imam mahdi or their own spiritual leader as the imam mahdi. The now defunct Malaysian-based Al-Arqam commune is one classic example, although such beliefs are not exclusive to them. This millenarian orientation shaped their worldviews and practices, with emphasis of continuing the tradition of their spiritual founders, and seeing their own congregation as the chosen group in the impending end of the world, in which the imam mahdi will appear, followed by Nabi Isa (Jesus Christ) in the final Armageddon. Another strand related to this is the belief in the chosenness of the ahlul bait, (a genealogy that claimed to be descendants of Prophet Muhammad) whose progeny in the leadership amongst the people will lead and usher in the new era of Islamic glory in the region.

\section{The theology amongst dakwah revivalists}

The populist dakwah revivalist theology becomes dominant in post-independent period. It is characterized by their puritanical stance. This group promoted a rather strict and exclusive definition of tauhid, of all that are outside is deemed unIslamic. Amongst the revivalists, otherwise known for their pamphleteer evangelism, in their ambivalent attitude towards the classical Islamic learning, sees Islam is a simple religion, a simple tauhidic

${ }^{3}$ Abdul Hadi W.M, Tasawuf yang Tertindas: Kajian Hermeneutik terhadap Karya-karya Hamzah Fansuri, Jakarta: Paramadina, 2001. 
theology with a clear cut legal precepts and command. It is no surprise that amongst the dakwah circles, in the concern over Muslims' public morality, Islamic law (fiqh), equated as divine law, is given prime emphasis in their dakwah repertoire. This neglect means a continuation of an orthodox type of theology. ${ }^{4}$

\section{Neo-traditionalist moderate reformist theology}

The traditional but mildly reformistic theology that emerged in the modern era, is a theology that is common amongst the religious establishment who associated themselves with the ideas of the reformist Egyptian Azharite's, Sheikh Muhammad Abduh, and the famous and highly respected Indonesian ulama, BuyaHamka. Many of the religious traditionalists are within this spectrum of theological affinity where teaching of wisdom (hikmah) and the adab traditions, are emphasized besides a strong observation of the legal precepts (fiqh) of Islam. Amongst these groups, albeit their firm stands on the orthodox theology, we see over time, a more receptive attitudes in the call to revitalize the faith, often phrased moderately. Their good grounding in the classical learning allows for some kind of openness and diversity of opinion. This strand is more eclectic in its theological views in comparison to those traditional orthodox kalam as well as those neo-orthodox revivalists.

\section{Liberative-transformative theology amongst progressives}

The transformative-liberative theologies as elaborated by the reformistprogressive Muslim thinkers/intellectuals are rather new phenomenon in the region's religious discourse. Their theological discourse is reflective of their engagement and response, on one hand, to the conservative

\footnotetext{
${ }^{4}$ Ibrahim Abu Bakar, "The Theologies of Muslim Modernists and Fundamentalists," Hamdard Islamicus, Vol. XXXII, No. 3 (2009), 45-66.
} 
religious traditionalism, and on the other, the exclusivist dakwah evangelism. Their theological thinking draws from various sources, namely from the prevailing conditions of the times, insights from social sciences, philosophy and humanities, apart from their exposure to classical and modern Islamic intellectual culture. This is the theological discourse that becomes the main analysis in this study.

The seven typologies above provide only a general outline on the types of theological orientations that can be found in Muslim Southeast Asia, though we must say that amongst them, there are constant interactions of each thought with another, and over time, it would be interesting to study these interactions and evolution which shaped the current Muslim thought in the religion, affecting beyond the theology proper. Perhaps one can add another category which we can call a "silent theology" that is actualized in the home environment. This is not a discourse of theology in a strict sense, but a socialization of theological ideas within a family or community setting where religious feelings, empathy, duties and symbolism are socialized at home. Dogmas are not delineated or rationalized, but the importance of good deeds and actions are emphasized. But in a more dynamic social societal setting, with more formalization of religious learning, this has surely, over time influence the silent theology itself. This subject, although interesting to look at, deserves a separate study of its own. ${ }^{5}$

\footnotetext{
${ }^{5} \mathrm{An}$ autobiographical statement by Nasr Abu Zaid is a good example that captures very well the example of the silent theology that is nurtured in the home and community setting. He wrote: "Much of my early religious education in the kuttab 'was rote. Recitation and memorization of the Qur'an took center stage...I had the entire Qur'an memorized...I did not comprehend much of what the text said. My father, my mother, the preacher in the mosque, and other folks in the village explained the text's meaning to me...Even as a child, I understood that Islam had everything to do with how you lived your life. The emphasis was on orthopraxis (proper behavior), not orthodoxy (proper belief or doctrine). Within my small community, I learned that the spirit of Islam was all about helping the poor and the weak. Today, I stand with the oppressed-whoever they are and whenever they may be." Nasr Abu Zaid, Voice of an Exile: Reflections on Islam, Westport, Conn.: Praeger, 2004, 63-64.
} 
Thus to study and understand this various stand is not simply for academic documentation, but identifying the key agents/actors that perpetuate and disseminate a certain type of theology. Essentially here we are dealing with their ideological outlook and the positions they occupied at a certain point in history. Generally most of these works are traditionalistic in orientation and hardly depart from the Sunni orthodoxy. Theology is generically termed as ilmu tauhid, ilmu kalam or usuluddin, and these are generally referred as "pristine" Islamic doctrinal teachings, untainted by modern ideas. The term "teologi" as used today may refer to the traditional theology, but it may also refer to the new ways of deliberating theology that is discursive, incorporating new themes deemed necessary for Muslims to make sense of their faith in the modern day context.

\section{Social theology as contextual theology in public sphere}

If in the West the public theology is an attempt to address the challenges of a privatized and the marginalization of theology, ${ }^{6}$ the case of Muslim Southeast Asia is a different one. In our case however, social theology as a theology in the public sphere, can be a discursive platform to challenge and correct certain imbalance of focus in the dominant theology, or in some cases, a critique on the theology that has been legitimated by the dominant religious establishment, both with and without the State. While there is no problem of the privatization of theology or the privatizing of religion as encountered in the West, in Muslim Southeast Asia, religion is still generally remains is a strong doctrinal, symbolic and mobilizing force in the lives and concern of the people, which no student of society should ignore or underestimate.

'Linell E. Cady, 'A Model for a Public Theology,' The Harvard Theological Review, Vol. 80, No. 2 (April 1987), 193-212 ; Martin Marty, "Reinhold Niebuhr: Public Theology and the American Experience," JR 54 (1974). 
However as one can say that there is no "marginalization" of theology in contemporary Muslim society, a closer and a critical look however into the religious discourse, will bear a more complex scenario. Whilst in the West, some theologians asserted the importance of public theology as a way to prevent privatization of theology; this can also be said in our case, except that the privatization does not mean an absence of Islam in the public sphere. This privatization of religion in our context means as long as theological teachings are approached as personal confession and dogmatic beliefs, with emphasis on personal salvation, the privatization of theology takes place, and this means a theology that will have a lesser efficacy or power to infect and affect the local surroundings. Hence if social theology attempts to address the privatized theology, the contributions of the reflective theological thinking by various scholars and writers are important.

In presenting the emerging discourse on social theology in Muslim Southeast Asia, we emphasize the importance of appreciating and evaluating the dominant ideas and those undercurrent ones in the religious traditions and orientations of the Malay-Indonesian Islam, thus at the same time, problematising the textual tendency with ahistorical analysis that are often made in the name of understanding Muslims in this region. While many noted the increasing Islamising tendencies from the standpoint of the larger dynamics of Islamisation since the seventies, there are not many who are interested to look seriously into the kind of religious orientations that are fermenting and dominating the people's lives at the local level. Herein lies the importance of analyzing the religious discourses that have emerged, contested and popularized by various groups and ideological interests. The emerging social theology, which is one of facet of the religious discourse, is reflective of the changing socio-political, cultural and economic factors in the region as well as the changing demography. 
Moreover the context of the emerging social theology in the region began in the period of Muslim religious resurgence in the seventies to the present time, where various shades and competing ideas are at the forefront of the local Islam discourse, although we can trace the genesis of the ideas of the social dimension in theology from the earlier reformist circles in the region. Ideas promoted in the emerging social theology not only presents alternative ones to the Muslim public, but signals a direct or subtle challenge to the dominant religious authority, which in turn made their own responses and articulate their counter discourses. Also, the emerging social theology as social discourse reflects a kind of democratization in Muslim religious teaching and learning. One writer noted this phenomenon:

"Increasingly today those without formal training in the Islamic disciplines claim direct interpretive rights over the Islamic texts as equals with the ulama, and in direct competition with them. ...New claims to Islamic intellectual authority are tied to the norms and expectations created by modern education. Compared with the exclusive, erudite and at times inaccessible repertoire of the ulama, new spokespersons for Islam frame their discourses in forms and accessible and relevant to modern -educated readerships, and adopt innovative techniques of interpretation." 7

It must be noted here that by bringing theology into the public sphere it is not so much because there is relegation or marginalization of doctrinal theology in Muslim discourse, but as a way to complement or simply presenting a new way of looking at and understand of theology, apart that it can also be a challenged to the secular groups that are ambivalent of, and indifferent to anything concerning religion, and think that there

${ }^{7}$ SuhaTaji-Farouki, Modern Muslim Intellectuals and the Qur'an, London: Oxford University Press, 2006, 14. 
is no place or any efficacy in the deliberation of social, political and economic issues when religion is computed in it. But it is not too far fetch to say that discoursing social theology in the public sphere has a tremendous educative effects to the younger generation as a form of knowledge which they can understand Islam and make sense of the world they live in, and this obviously warrants us to look into the discourse critically.

\section{The 'new' ways of theologising}

Today in Southeast Asia we see several books and articles written which can be classified as belonging to this genre of social theology. The mainstream theology, as taught and accepted, still bears a continuity of the traditional orthodox theology. There is of course suggestion that the mainstream theology itself needs revision and reformulation, but we yet to see a new systematic and comprehensive theology yet to be written, ${ }^{8}$ although there are surely those who write about theological themes but not organized in a specifically genre of theology, ${ }^{9}$ nor labeling their works specifically as theology.

Generally there are a number of books that discusses on teologi/kalam from a descriptive historical standpoint. Often, the discussion on Islamic theology begins and ends with the medieval theological formulations and contestations since the seventh to thirteenth century. ${ }^{10}$ This includes trans-

${ }^{8}$ Perhaps one can highlight here the attempt of MulyadhiKertanegara. Read, Mulyadi Kertanegara, "Merintis Sebuah Teologi Baru," in H. Abdul Halim (ed.) Teologi Islam Rasional: Apresiasi terhadap Wacanadan Praksis Harun Nasution, Jakarta: Ciputat Press, 2005, 97-107 and his Nalar Religius: Memahami Hakikat Tuhan, Alam, dan Manusia, Jakarta: Penerbit Erlangga, 2007.

9 A. Hanafi's Pengantar Teologi Islam perhaps is one exception, although the content is still very much traditional in outlook.

${ }^{10}$ H.M. Laily Mansur, Pemikiran Kalam dalam Islam, Jakarta: Pustaka Firdaus, 2004; Hamzah Ya'qub, Kuliah Ilmu Tauhid (Ilmu Kalam), Singapura: Pustaka Nasional, 1988; Sahilun A. Nasir, Ilmu Kalam: Pengertian, Sejarah dan Perkembangannya, Surabaya: Bina Ilmu, 1980; M. Hasbi, T. Ash Shiddieqy, Sejarah dan Pengantar Ilmu Tauhid/Kalam, Jakarta: Bulan Bintang,1973; AboebakarAtjeh, Ilmu Ketuhanan (Ilmu Kalam), Djakarta: Tintamas, 1966. 
lations of past works on theology by classical ${ }^{11}$ and modern day writers ${ }^{12}$ or study on theological thought of leading ulama from this region ${ }^{13}$ or abroad in the past. ${ }^{14}$ Not only there are more discussions on theology in various perspectives and concern, there is also synoptic study on the theological thought of prominent Indonesians scholar-theologian like Hamka, ${ }^{15}$ Nurcholish Madjid ${ }^{16}$ and QuraishShihab. ${ }^{17}$ There is even a specific study devoted for analyzing the theological thought of Rashid Rida ${ }^{18}$ and Fazlur Rahman. ${ }^{19}$

In Indonesia particulary, the discursive social theology and this can be noted in the advocation for and deliberation of teologi rasional (HarunNasution), teologi kemanusiaan (Nurcholish Madjid) teologi transformatif (Moeslim Abdurrahman), teologi kebudayaan (Abdul Munir Mulkhan), tauhid sosial (Amien Rais), teologi kaum tertindas (Mansour Fakih), ilmu sosial profetik (Kuntowijoyo), and few others. In the Malaysian case, we shall refer to the works of Za'ba, Syed Hussein Alatas, Syed Muhammad Naguib al-Attas, Chandra Muzaffar, Kassim Ahmad, Faisal Othman and Mohd Asri Zainal Abidin and few others. Collectively their

${ }^{11}$ Al-Syahrastani, Al-Milal wa Al-Nihal (Aliran-aliran Teologi dalam Islam), Bandung: Mizan Pustaka, 1988.

${ }^{12}$ Muhammad 'Ata Al Sid, Sejarah Kalam Tuhan: Kaum Beriman Menalar al-Quran Masa Nabi, Klasik dan Modern, Jakarta: Penerbit Teraju, 2004; Muhammad Maghfur W., Koreksi atas Kesalahan Pemikiran Kalam dan Filsafat Islam, Bangil: Al-Izzah, 2002.

${ }^{13}$ Muhammad Nazir Karim, Dialektika Teologi Islam: Analsis Pemikiran Kalam Syeikh Abdurrahman Shiddiq al-Banjari, Bandung: Penerbit Nuansa, 2004.

${ }^{14}$ Tsuroya Kiswati, Al-Juwaini: Peletak Dasar Teologi Rasional dalam Islam, Jakarta: Erlangga, 2005.

${ }^{15}$ M. Yunan Yusuf, Corak Pemikiran Kalam Tafsir al-Azhar: Sebuah Telaah tentang Pemikiran Hamka dalam Teologi Islam, Jakarta: Pustaka Panjimas, 1990.

${ }^{16}$ Sukidi, Teologi Inklusif Cak Nur, Jakarta: Kompas, 2001.

${ }^{17}$ Mustafa P. M., Qurasih Shihab Membumikan Kalam di Indonesia, Yogyakarta: Pustaka Pelajar, 2010.

${ }^{18}$ A Athaillah, Rasyid Ridha: Konsep Teologi Rasional dalam Tafsir al-Manar, Jakarta: Erlangga, 2006.

${ }^{19}$ Abd. A'la, Dari Neo Modernisme Ke Islam Liberal, Jakarta: Dian Rakyat \& Paramadina, 2009. 
works are diverse in themes and styles, but all generally directed at creating a new religious/theological discourse (when compared to the previous traditional ones), giving space for critical social sciences and social philosophy to be incorporated, thus challenging the dominant theology of traditionalistic Islam.

Kuntowijoyo was one of the leading exponents of this prophetic theology in Indonesia, even though he did not use the term teologi to refer to his discussion. He was even invited to Malaysia, which he delivered a lecture on the same theme. ${ }^{20}$

Generally the writers or advocates of the new theology see not only that Muslims need a reformistic or transformative theology, but the very domain of theology or ways of theologizing must be reformed. To them, theology can no longer privilege itself in doctrinal expositions, but a theology that ready to take up social critiques inasmuch as it discusses on the religious orientations of the believers. This new theologizing efforts should be seen as a reformistic conviction and endeavors amongst its advocates. The call for reforms so far centered on the legal interpretations, religious education and how Muslims should adapt and accommodate in the face pace modernity. Reforming or rethinking theology is almost unheard of, if not totally unthinkable. Nevertheless over the years, we see the gradual and serious efforts, albeit disparate, in talking about the need for a new kind of theology that enables Muslims to rethink some of their earlier positions and reconstruct the religious thought which should have a direct bearing on their actions and comprehension of the present world.

When we say the "new" ways of theologizing, we need to make some qualifications. The 'new' suggests forms of expressions and priorities of

20 See Kuntowijoyo, Ilmu Sosial Profetik sebagai Gerakan Intelektual, Kajang: Akademi Kajian Ketamadunan, 2004. To the extent his ideas gained acceptance in the Malaysian discourse is yet to be seen. 
thematic concerns. 'New' does not mean bringing an entirely new concepts alien to the religious tradition. It is new in the sense that: a) the subject matters are contemporary themes are taken up, where these themes have been fairly underdeveloped in its focus and depth in the conventional, dominant theology; b) the appropriation of current issues, namely politics, culture, economics and social that are affecting society, in which the traditional theology are not concerned with it, or have the conceptual tools to deliberate it; c) theology is no longer an exclusive domain where aspects of the doctrines are elaborated but also justifying other important themes that are central to the life of the believers. Here theology becomes both a site for religious criticism of the conventional beliefs, as well as a site in resisting dehumanizing and oppressive ideas and practices.

This new theologizing approach does not only address the contextual needs of the present society, but also sensitive of the particularistic concern that should shape the contours, colors and tenor of the local theology. In the case of Southeast Asian Islam, this is an important point for an Arabo-centric religious discourse has predominated for a long time, both in content and expression. A new theology is cognizant of the fact that Arabicness should not be equated to Islam, as the universality of Islam gives all particular cultures equal standing and recognition. ${ }^{21} \mathrm{We}$ shall come back to this point when we discuss the recognition for an indigenized Islam (pribumisasi Islam) in Indonesia and the imperative need to build a local theology.

What we see today is a form and tenor of theology that is taking more a social and political face, one that has a strong humanistic affiliation

\footnotetext{
${ }^{21}$ Read Khamami Zada, M. Imddaun Rahmat, Abd Moqsith Ghazali \& Musoffa Basyir, "Menolak Arabisme, Mencari Wajah Islam Indonesia," in Zuhairi Misrawi, (ed.), Menggugat Tradisi: Pergulatan Pemikiran Anak Muda NU, Jakarta: Kompas, 2004.
} 
with greater socio-cultural and socio-economic concerns. It is no longer the devotional, creedal orthodox theology which is more concern with individual ethic and spiritual contemplation. This does not mean that this devotional theology (in contrast to social theology) no longer in use. On the contrary it is still widespread, while there is a new way of theologising that is emerging, not just new themes that are incorporated but also a new site or public space in which theology is deliberated and discussed. This is significant where in the past, theology was mainly [re]produced and studied within the confines of the santri community, and only to be disseminated to the Muslim population in a watered-down version.

Hence in its presence and articulation in the public space, (beyond the confines of pesantren/pondok/madrasah) social theology as a religious discourse no longer could be in the sole purview or monopoly of the learned custodian. This means no special or specific groups can claim to monopolise it. The discourse is then can be subjected to critical scrutiny and challenge. Best if this social theology itself can be seen, and taken seriously in the social science domain, or the general intellectual discourse, where dialectical and competing ideas will augur well for its further development and refinement of theological-social thought.

It is interesting to note that the writers/scholars who engaged in this realm of social theology rarely take the posture as a theologian or identified themselves as ulama. They are more concern to address the Muslim public, rather than the small religious circles, the seminaries or congregation. This is the spatial dimension that characterized social theology as mentioned earlier. Social theology as developed by the progressive religious intellectuals, in many ways is important as it is also a site where ideas from the traditionalist and revivalists are taken up and debated. This in turn prevents the usurpation and monopoly of theological discus- 
sions in the hands of the exclusivist fundamentalist and revivalist. The mostly unarticulated traditional theology, which emphasized heavily on piety and conformity, could not surmount the challenge of fundamentalist theology that is evocative and appealing to the Muslim public, especially when very little alternative ideas are available at their disposal. This is what exactly happened in the era of dakwah revivalist resurgence in the seventies. Thus the engagement of social theology in the public sphere means to recognize the fact that theology or other religious discourses for that matter, is too important to be left exclusively to the ulamas, santris and asatizahs, albeit their participation is crucial.

Social theology opens a wider realm of participation and engagement, where theology is no longer the exclusive affairs of experts, but inclusive of the lay intellectuals who are not necessarily from a strictly religious background or learning institutions. It functions to provide alternative, or at least to supplement the doctrinal theology that sanctified the dogma into the esoteric and legal realms in the belief system. It also enables the Muslim public to comprehend critically and to cope creatively with rapid social change, and its attendant problems. It must be emphasized here that as it is a discourse concern about contemporary issues, it is therefore not a corpus that detailed all the past theological formulations and arguments, but it is one that is contextual, forward looking and inspire religious vision and clarity. It should provide new ways of understanding the religious, not simply clarifying the teachings but also able to address the issues and problems of the times. Theology after all a human enterprise, albeit its strong religious commitment.

Last but not least, the potentiality of social theology lies in the socialization of reformistic and enlightened ideas to the general Muslim public. Being reformistic and critical in its positions, there will inevitably objections to social theology as doctrinally aberrant or bereft of spirituality. The 
charged of being Western influence can always be expected. The defense for the authentic theology as imagined by the conservatives needs to be anticipated and debated. In this regards the epistemic clarity must be made available. This new theology needs a sound epistemic basis, as a defense against the accusation of doctrinal aberration from its adversaries.

\section{Bibliography}

A’la, Abd. Dari Neo Modernisme Ke Islam Liberal. Jakarta: Dian Rakyat \& Paramadina, 2009.

Atjeh, Aboebakar. Ilmu Ketuhanan (Ilmu Kalam). Djakarta: Tintamas, 1966.

Athaillah, A. Rasyid Ridha: Konsep Teologi Rasional dalam Tafsir al-Manar. Jakarta: Erlangga, 2006.

Al-Attas, Syed Muhammad Naquib (ed.). The Oldest Known Malay Manuscript: a 16th Century Malay Translation of the 'Aqa'id of al-Nasafi. Kuala Lumpur: University of Malaya, 1988.

Bakar, Ibrahim Abu, "The Theologies of Muslim Modernists and Fundamentalists," Hamdard Islamicus, Vol. XXXII, No. 3 (2009): 45-66.

Cady,Linell E., "A Model for a Public Theology," The Harvard Theological Review, Vol. 80, No. 2 (April 1987): 193-212.

Drewes, G. W. J. (ed.). Directions for Travellers on the Mystic Path: Zakariyya alAnsari's Kitab Fath al-Rahman and Its Indonesian Adaptations: with an Appendix on Palembang Manuscripts and Authors. The Hague: Nijhoff, 1977.

Farouki, SuhaTaji. Modern Muslim Intellectuals and the Qur'an. London: Oxford University Press, 2006.

Hadi W.M, Abdul. Tasawuf yang Tertindas: Kajian Hermeneutik terhadap Karyakarya HamzahFansuri. Jakarta: Paramadina, 2001.

Karim, Muhammad Nazir. Dialektika Teologi Islam: Analsis Pemikiran Kalam Syeikh Abdurrahman Shiddiq al-Banjari. Bandung: Penerbit Nuansa, 2004. 
IJIMS, Indonesian Journal of Islam and Muslim Societies, Volume 4, Number 1, June 2014: 1-23

Kertanegara, Mulyadi, "Merintis Sebuah Teologi Baru," in H. Abdul Halim (ed.) Teologi Islam Rasional: Apresiasi terhadap Wacanadan Praksis Harun Nasution. Jakarta: Ciputat Press, 2005.

Kertanegara, Mulyadi. Nalar Religius: Memahami Hakikat Tuhan, Alam, dan Manusia. Jakarta: Penerbit Erlangga, 2007.

Kiswati, Tsuroya. Al-Juwaini: Peletak Dasar Teologi Rasional dalam Islam. Jakarta: Erlangga, 2005.

Kuntowijoyo. Ilmu Sosial Profetik sebagai Gerakan Intelektual. Kajang: Akademi Kajian Ketamadunan, 2004.

Maghfur W., Muhammad. Koreksi atas Kesalahan Pemikiran Kalam dan Filsafat Islam. Bangil: Al-Izzah, 2002.

Mansur, H.M. Laily. Pemikiran Kalam dalam Islam. Jakarta:PustakaFirdaus, 2004.

Marty, Martin, "Reinhold Niebuhr: Public Theology and the American Experience," JR 54 (1974).

Nasir, Sahilun A. Ilmu Kalam: Pengertian, Sejarah dan Perkembangannya. Surabaya: Bina Ilmu, 1980.

P. M. Mustafa. Qurasih Shihab Membumikan Kalam di Indonesia. Yogyakarta: Pustaka Pelajar, 2010.

Riddell, Peter. Transferring a Tradition :Abd al-Ra'uf al-Singkili's Rendering into Malay of the Jalalayn Commentary, Berkeley, CA: University of California, Centers for South and Southeast Asia Studies, 1990.

Riddell, Peter, "Controversy in Qur'anic Exegesis and Its Relevance to the Malays-Indonesian World," in Anthony Reid (ed.). The making of an Islamic political discourse in Southeast Asia. Clayton, Vic.: Centre of Southeast Asian Studies, Monash University, 1993.

Shiddieqy, M. Hasbi, T. Ash. Sejarah dan Pengantar Ilmu Tauhid/Kalam. Jakarta: Bulan Bintang, 1973. 
Al-Sid, Muhammad 'Ata. Sejarah Kalam Tuhan: Kaum Beriman Menalar al-Quran Masa Nabi, Klasik dan Modern. Jakarta: Penerbit Teraju, 2004.

Sukidi. Teologi Inklusif Cak Nur. Jakarta: Kompas, 2001.

Al-Syahrastani. Al-Milal wa Al-Nihal (Aliran-aliran Teologi dalam Islam). Bandung: Mizan Pustaka, 1988.

Ya'qub, Hamzah. Kuliah Ilmu Tauhid (Ilmu Kalam). Singapura: Pustaka Nasional, 1988.

Yusuf, M. Yunan. Corak Pemikiran Kalam Tafsir al-Azhar: Sebuah Telaah tentang Pemikiran Hamka dalam Teologi Islam. Jakarta : Pustaka Panjimas, 1990.

Zada, Khamami, M. Imddaun Rahmat, Abd Moqsith Ghazali \& Musoffa Basyir, "Menolak Arabisme, Mencari Wajah Islam Indonesia," in Zuhairi Misrawi (ed.). Menggugat Tradisi: Pergulatan Pemikiran Anak Muda NU. Jakarta: Kompas, 2004.

Zaid, Nasr Abu. Voice of an Exile: Reflections on Islam. Westport, Conn. : Praeger, 2004. 